\title{
Simulasi Antrian Jaringan Multi Server Menggunakan Metode Open Jackson
}

\author{
I Wayan Supriana*1, Subanar ${ }^{2}$ \\ ${ }^{1}$ Jurusan Ilmu Komputer, FMIPA UNUD, Denpasar \\ ${ }^{3}$ Jurusan Ilmu Komputer dan Elektronika, FMIPA UGM, Yogyakarta \\ e-mail: *11wayansupriana@gmail.com, ${ }^{2}$ subanar@yahoo.com
}

\begin{abstract}
Abstrak
Antrian paket data pada jaringan komputer memiliki model antrian jaringan, dimana proses transmisi yang rumit sehingga tidak dapat diselesaikan secara analitik. Pemodelan dan simulasi diperlukan untuk menyelesaikan masalah antrian jaringan.

Model antrian dalam penelitian ini adalah jaringan terbuka dengan analisis paket data menggunakan model server tunggal. Waktu pelayanan paket memiliki distribusi Eksponensial dan distribusi Erlang yang digunakan sebagai pembanding. Jika waktu pelayanan paket data menggunakan distribusi Eksponensial maka model menjadi M/M/1, sedangkan waktu pelayanan paket data menggunakan distribusi Erlang dengan parameter $m$ dan $\mu$, maka model menjadi $M / E_{[m /} / 1$.

Penelitian ini menggunakan metode open Jackson untuk melakukan simulasi antrian jaringan guna menghitung nilai karakteristik jaringan. Pengujian sistem simulasi menggunakan packet switching network pada server jaringan komputer Jurusan Ilmu Komputer Universitas Udayana untuk mengetahui performansi sistem yang menggunakan distribusi waktu pelayanan berbeda. Hasil pengujian menunjukkan bahwa waktu pelayanan distribusi Eksponensial memiliki karakteristik yang lebih baik dari distribusi Erlang pada parameter $m$-Erlang $\geq 2$.
\end{abstract}

Kata kunci-antrian jaringan, distribusi,sistem performansi, multi server.

\begin{abstract}
Queue data packet at computer network having a network queueing model, with complicated transmission process so that it can not be solved analytically. Modeling and simulation are needed to resolve the issue queue network.

Queueing model in this research is an open network with the analysis of data packet using a single server model. Service time packet has Exponential distribution and Erlang used as comparison. If the service time of data packet using the Exponential distribution, then the model become $M / M / 1$, whereas the service time using the Erlang distribution with parameter $m$ and $\mu$, then the model becomes $M / E_{[m]} / 1$.

This research uses an open Jackson method to perform queueing network simulations to calculate the characteristics of network queueing system. Examination of simulation system uses data packets on a computer network server of Department Computer Science University of Udayana to determine system performance using with different service time distribution. The result of examination indicate that service time of Exponential distribution has better characteristic then Erlang distribution at parameter $m$-Erlang $\geq 2$.
\end{abstract}

Keywords—queueing network, distribution, system performance, multiple server 


\section{PENDAHULUAN}

$\mathrm{M}$ eningkatnya lalu lintas aliran paket data pada jaringan komputer yang tidak diimbangi dengan peningkatan pelayanan akan menimbulkan antrian terhadap paket data sampai tersedianya sarana untuk proses pelayanan. Antrian yang terjadi memiliki model jaringan dimana paket data akan dilayani oleh beberapa node sampai paket tersebut ke tujuan.

Berbagai model pendekatan telah dilakukan untuk mengkaji masalah antrian jaringan seperti BCMP dalam [1], Gordon dan Newell dalam [2] serta antrian jaringan Jackson dalam [3]. Jackson memberikan definisi yang lebih baik dari kelas antrian jaringan BCMP dan kelas antrian jaringan Gordon dan Newell. Model antrian jaringan Jackson memberikan distribusi kesetimbangan gabungan sebagai produk dari distribusi kesetimbangan antrian individu.

Teknik-teknik penyelesaian yang optimal seperti analitik dan teori antrian yang memiliki formula yang telah ditetapkan digunakan untuk menyelesaikan masalah antrian jaringan. Antrian paket data pada jaringan komputer memiliki proses transmisi yang sangat kompleks sehingga tidak memungkinkan dianalisis secara analitik, maka dari itu diperlukan suatu pemodelan dan simulasi yang mempresentasikan sistem guna mengamati prilaku dari sistem dengan tujuan memperkirakan dan akhirnya meningkatkan kinerja sistem.

Pemodelan dan simulasi digunakan untuk memperkirakan situasi antrian sesungguhnya, sehingga kelakukan antrian dapat dianalisis. Dengan model sistem antrian maka akan dapat dimungkinkan untuk menentukan ukuran performansi sebagai isu yang disebabkan oleh situasi antrian yang terkait dengan masalah kecepatan pelayanan. Analisis terhadap model antrian yang tepat akan memungkinkan penyebab antrian diidentifikasi dan akibat-akibatnya dapat diminimalisasi.

Dalam penelitian ini, pendekatan simulasi dengan metode open Jackson dilakukan untuk menyelesaikan masalah antrian jaringan. Antrian jaringan Jackson memodelkan paket data dari lingkungan eksternal tiba ke jaringan membentuk proses Poisson yang memiliki disiplin antrian FCFS dan berpindah dengan probabilistik ke node berikutnya setelah selesai dikerjakan di node sebelumnya dengan layanan tertentu. Antrian jaringan Jackson memiliki sifat berkesinambungan di setiap node yang memberikan layanan untuk masing-masing antrian yang independen satu sama lain sehingga memungkinkan untuk menganalisis setiap node secara terpisah dengan menggunakan waktu pelayanan berdistribusi berbeda.

Beberapa penelitian yang pernah dilakukan dan yang terkait dengan penelitian yang dilakukan seperti, penelitian yang dilakukan [4] tentang antrian paket switching pada jaringan komputer menggunakan model manajemen dan kontrol orientasi kemacetan untuk menganalisis sistem. [5] tentang model antrian jaringan dengan blocking pada analisis aliran antrian pasien dalam sistem pelayanan kesehatan mental dengan metode numerik. [6] tentang dinamic importance sampling untuk antrian jaringan yaitu mengatasi buffer overflow dalam stabilitas antrian jaringan Jackson dengan metode analitik. [7] tentang pengaturan eksternal yang terjadi pada antrian jaringan tempat wisata menggunakan model antrian jaringan Jackson dengan metode analitik.penelitian yang dilakukan [8] tentang simulasi antrian multiple server dengan pola kedatangan pelanggan secara berkelompok. Digunakan Pemodelan dan simulasi untuk menyelesaikan masalah antrian dengan waktu pelayanan pelanggan didistribusikan secara Eksponensial dan Erlang yang digunakan sebagai pembanding.

Permasalahan yang dibahas pada penelitian ini adalah bagaimana membuat pemodelan dan simulasi dengan menerapkan metode open Jackson pada antrian jaringan multi server guna mengetahui karakteristik sistem dimana waktu pelayanan paket data didistribusikan Eksponensial dan Erlang yang digunakan sebagai pembanding. 


\section{METODE PENELITIAN}

\subsection{Model Sistem Antrian Jaringan}

Antrian jaringan yang dibahas dalam penelitian ini adalah antrian jaringan terbuka dengan metode open Jackson yang mensimulasikan paket data switching network pada server jaringan komputer Jurusan Ilmu Komputer Universitas Udayana untuk menentukan karakteristik sistem yang memiliki pola antrian paket data model jaringan.

Model sistem memiliki interkoneksi aliran data pada ketiga server yaitu mail server, web server dan ripository server yang ditunjukkan pada Gambar 1 . Dengan $\lambda$ merupakan tingkat kedatangan, $\mu$ tingkat pelayanan, $k$ jumlah node, $r$ tingkat kedatangan eksternal dan $p_{i j}$ merupakan probabilitas paket dari node $i$ ke node $j$.

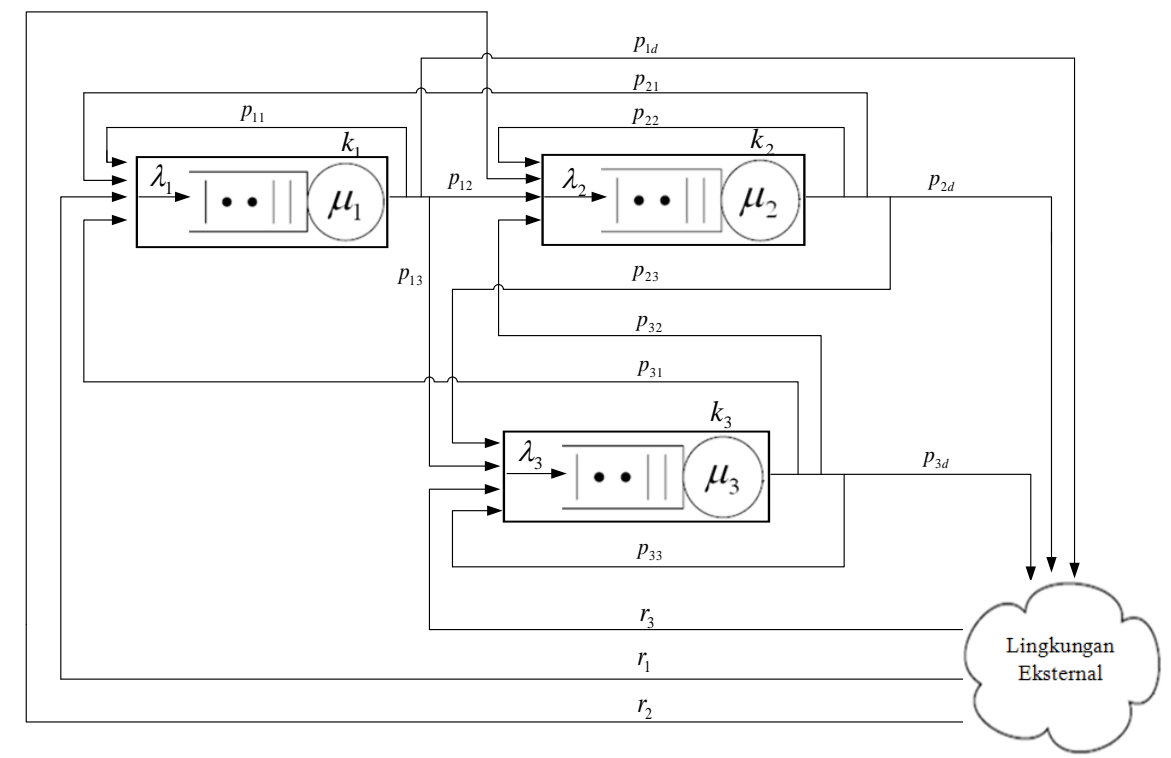

Gambar 1. Aliran data model sistem antrian jaringan

\section{1.1 Performansi Model Sistem Antrian Jaringan}

Model sistem antrian jaringan Jackson memiliki sifat steady state sehingga untuk mengukur performansi jaringan menggunakan persamaan berikut;

1. Probabilitas jaringan antrian $p(n)$ menunjukkan efektifitas dan efisiensi dari antrian dengan persamaan berikut:

$$
p(n)=\prod_{i=1}^{K}\left(1-\rho_{i}\right) \rho_{i}^{n_{i}}, \rho_{i}=\frac{\lambda_{i}}{\mu_{i}}
$$

Dimana $\rho_{i}$ utilitas node $i$ dan $n_{\text {i }}$ paket pada node $i$

2. Stabilitas sistem antrian jaringan apabila memenuhi persamaan sebagai berikut:

$\lambda . p(n)<\mu . k$

3. Karakteristik paket data pada masing-masing node dihitung dengan persamaan berikut:

Waktu tunggu paket dalam antrian pada node $i$

(waktu dimulai pelayanan-waktu kedatangan paket)

Waktu tunggu paket pada node $i$

(waktu selesai pelayanan-waktu kedatangan paket)

Rerata waktu tunggu paket dalam antrian pada node $i$

$$
\frac{\sum \text { waktutunggu paket data dalam antrian }}{\text { Total paket data }}
$$

Rerata waktu tunggu paket data dalam node $i$ 
$\sum$ waktu tunggu paket data dalam node $i$

Rerata jumlah paket data dalam antrian pada node $i$

$\sum$ waktu tunggu paket data dalam antrian

$$
\text { Durasi }
$$

Rerata jumlah paket dalam node $i$

$$
\frac{\sum \text { waktu tunggu paket data dalam node } i}{\text { Durasi }}
$$

4. Karakteristik sistem antrian jaringan dihitung dengan persamaan berikut:

Rerata waktu tunggu paket data dalam antrian pada sistem jaringan

$$
\frac{\sum_{i=1}^{k} \text { Rata - rata waktu tunggu paket data dalam antrian pada node } i}{\text { Banyaknya node }}
$$

Rerata waktu tunggu paket data pada node di dalam sistem jaringan

$\sum_{i=1}^{k}$ Rata - rata waktu tunggu paket data dalam node $i$

$$
\text { Banyaknya node }
$$

Rerata jumlah paket data dalam sistem jaringan

$$
\frac{\sum_{i=1}^{k} \text { Rata - rata jumlah paket data dalam node } i}{\text { Banyaknya node }}
$$

Rerata waktu pelayanan paket data dalam sistem jaringan

$\underline{\sum_{i=1}^{k} \text { Jumlah waktu pelayanan node } i}$

Total paket data

Probabilitas node sistem jaringan sibuk

$$
\frac{\sum_{i=1}^{k} \text { Jumlah waktu pelayanan node } i}{\text { Banyaknyanode * Durasi }}
$$

\section{1.2 Uji Kerandoman}

Uji kerandoman paket data menggunakan runs test of randomness yang menguji apakah bilangan random yang dihasilkan benar-benar random berdasarkan [9], maka persamaan yang harus dipenuhi sebagai berikut:

$$
r_{\text {lower }} \leq r \leq r_{\text {upper }}
$$

Dengan $\alpha=0.05$ (5\% level of significance)

$$
\begin{aligned}
& r_{\text {lower }}=\frac{2 n-1}{3}-1.96 * \sqrt{\frac{16 n-29}{90}} \\
& r_{\text {upper }}=\frac{2 n-1}{3}+1.96 * \sqrt{\frac{16 n-29}{90}}
\end{aligned}
$$

Jumlah $r$ ditentukan dengan membandingkan data random pertama dengan kedua, kedua dengan ketiga dan seterusnya sampai $\mathrm{n}$ data random. Hasil pembandingan setiap data dberi tanda $(+)$ jika datanya naik dan tanda (-) jika datanya menurun. $r$ dihitung dengan menjumlahkan hasil pembandingan data random.

\section{1.3 Penyelesaian dengan Simulasi}

Simulasi digunakan untuk menjabarkan atau memprediksi bagaimana sebuah sistem akan mengoprasikan suatu pilihan yang ditentukan untuk controllable input dan nilai yang akan 
dihasilkan secara random untuk probabilistic input. Alur proses simulasi dijelaskan pada Gambar 2. Tahapan-tahapan proses simulasi secara umum diuraikan sebagai berikut:

1. Masukkan parameter controllable input yang berupa banyaknya node dan durasi simulasi serta untuk masing-masing node controllable input berupa tingkat kedatangan, tingkat pelayanan dan jumlah paket internal sistem.

2. Lakukan pengujian terhadap controllable input untuk stabilitas sistem pada saat pertama diproses.

3. Lakukan proses simulasi

4. Sistem mengenerate kedatangan paket data dari eksternal sistem.

5. Generate bilangan random sebanyak total paket dari internal dan eksternal sistem.

6. Sistem melakukan proses pengujian bilangan random.

7. Sistem melakukan proses pelayanan paket dengan distribusi Eksponensial dan distribusi Erlang.

8. Sistem melakukan proses routing paket data.

9. Hasil akhir simulasi adalah karakteristik sistem berdasarkan distribusi waktu pelayanan paket.

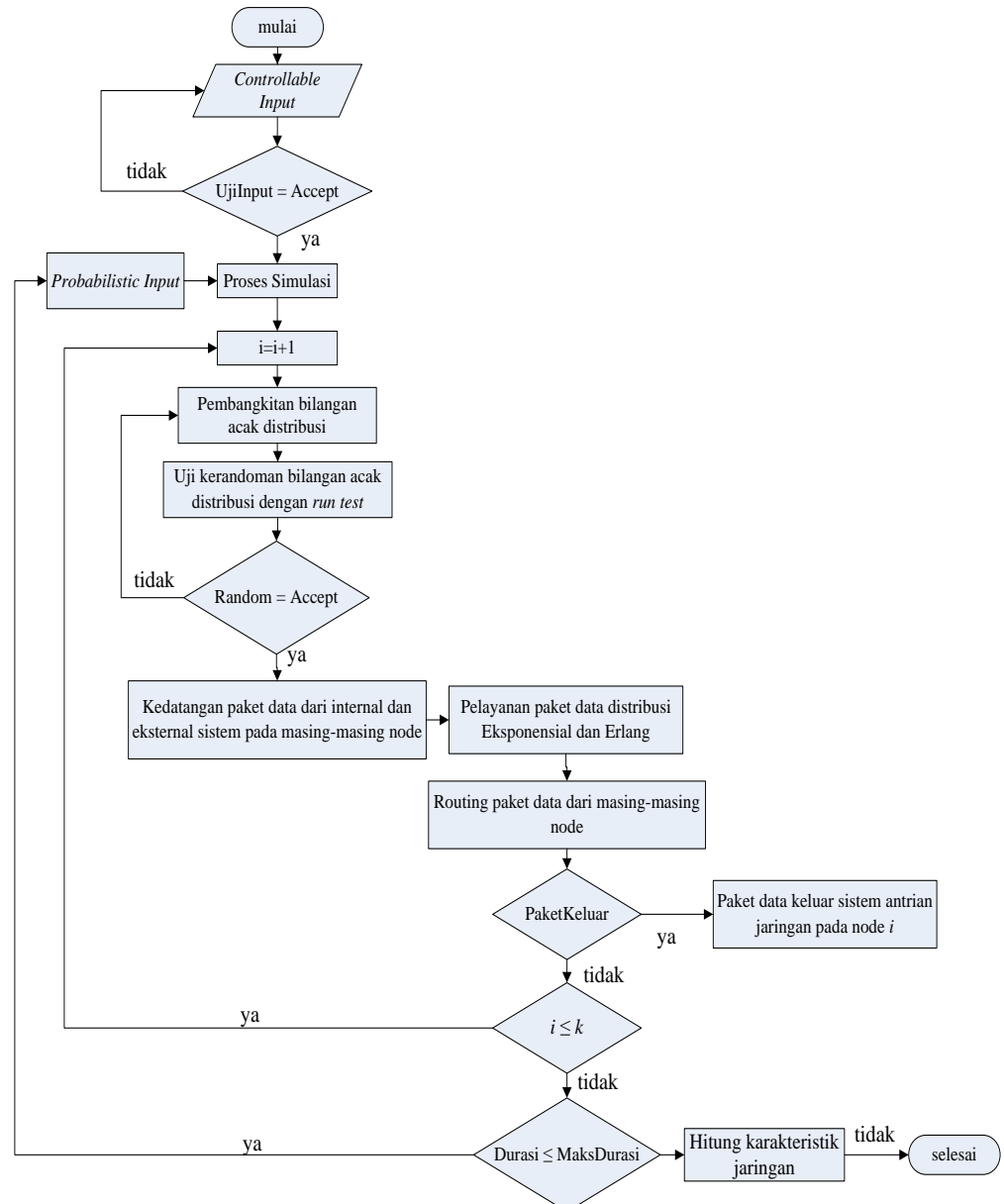

Gambar 2. Flowchart sistem simulasi antrian jaringan

\subsection{Model Sistem Antrian Jaringan}

Berdasarkan model yang telah didisain dirancang langkah-langkah dalam setiap proses simulasi yang diuraikan sebagai berikut: 


\section{2.1 Proses Input Parameter}

Proses input parameter sistem yang merupakan proses awal memulai simulasi dijelaskan dengan langkah-langkah sebagai berikut:

1. Menentukan controllable input sistem.

2. Lakukan proses perhitungan controllable input untuk menentukan distribusi probabilitas steady state dengan persamaan (5).

3. Lakukan pengujian stabilitas sistem pada masing-masing node dengan persamaan (6).

4. Proses simulasi berjalan ketika stabilitas sistem dipenuhi oleh seluruh node.

\section{2.2 Proses Generate Bilangan Random Distribusi Poisson}

Proses generate bilangan random distribusi Poisson digunakan untuk menentukan pembangkitan bilangan random Poisson dan pembangkitan paket data dari eksternal sistem, dengan langkah-langkah proses sebagai berikut:

1. Tentukan tingkat kedatangan dari controllable input.

2. Lakukan proses perhitungan $f=e^{-\lambda}$ dengan $F=f$

3. Generate bilangan random distribusi seragam $U(0,1)$.

4. Bandingkan bilangan random distribusi seragam dengan $F$, jika labih besar lakukan proses rekursif distribusi Poisson, jika tidak maka cetak nilai $x$ dengan kejadian sukses per unit.

5. Lakukan proses perhitungan Poisson dengan persamaan berikut: $\frac{e^{-\lambda} \lambda^{x}}{x !}$

6. Lakukan proses penjumlahan total Poisson pada proses (5).

7. Lakukan proses penjumlahan $x$ untuk menghitung total paket eksternal sistem pada proses (4).

8. Bilangan random Poisson dihitung dengan menjumlahkan total Poisson dibagi dengan paket data internal sistem, proses yang sama dilakukan tiap node.

\section{2.3 Proses Generate Bilangan Random Distribusi Eksponensial}

Proses ini digunakan dalam perhitungan service time pelayanan distribusi Eksponensial dengan langkah-langkah sebagai berikut:

1. Tentukan tingkat pelayanan setiap node.

2. Generate bilangan random distribusi seragam $U(0,1)$.

3. Lakukan proses perhitungan nilai $x$ dengan persamaan berikut: $x=-\frac{1}{\mu} \ln (1-U)$

4. Generate bilangan random distribusi Eksponensial dengan persamaan berikut: BilRandEk $=1-e^{-\mu x}$.

5. Lakukan proses (c) sampai (d) pada tiap paket data dalam seluruh node jaringan.

\section{2.4 Proses Generate Bilangan Random Distribusi Erlang}

Proses ini digunakan dalam perhitungan service time pelayanan distribusi Erlang dengan langkah-langkah sebagai berikut:

1. Tentukan tingkat pelayanan setiap node.

2. Tentukan bilangan random distribusi Eksponensial $\left(\mathrm{r}_{N}\right)$ yang sudah digenerate.

3. Lakukan proses perhitungan nilai $x$ dengan persamaan berikut: $x=\prod_{i=1}^{N}\left(1-r_{i}\right)$

4. Generate bilangan random distribusi Erlang dengan persamaan berikut: $B i l R a n d E r=-\frac{1}{N \mu} \ln (x)$

5. Lakukan proses (c) sampai (d) pada tiap paket data dalam seluruh node jaringan. 


\section{2.5 Proses Uji Kerandoman}

Pengujian bilangan random menggunakan metode runs test dengan langkah-langkah proses sebagai berikut:

1. Ambil data random yang sudah di generate.

2. Tandai data dengan (+) jika data naik dan (-) jika data menurun.

3. Hitung jumlah runs dari data yang sudah di tandai.

4. Hitung nilai $r_{\text {lower }}$ dengan persamaan (19).

5. Hitung nilai $r_{\text {upper }}$ dengan persamaan (20).

6. Lakukan proses pengecekan dengan kondisi $r_{\text {lower }} \leq r \leq r_{\text {upper }}$, jika memenuhi kondisi tersebut maka data random diterima oleh sistem.

\section{2.6 Proses Kedatangan Paket Data}

Proses kedatangan paket terdiri dari internal dan eksternal sistem yang dijelaskan pada Gambar 3. Langkah-langkah proses kedatangan adalah sebagai berikut:

1. Tentukan tingkat kedatangan paket data.

2. Tentukan kedatangan eksternal sistem yang di generate pada generator distribusi Poisson.

3. Tentukan kedatangan internal sistem dimana pada proses awal kedatangan internal sistem ditentukan dari controllable input yang selanjutnya ditentukan berdasarkan routing paket.

4. Generate bilangan random distribusi seragam untuk proses perhitungan inter arrival time (iat).

5. Lakukan proses perhitungan iat, Jika kedatangan untuk pelayanan distribusi Erlang maka nilai rate menjadi stage $* \lambda$, sedangkan untuk distribusi Eksponensial nilai ratenya tetap yaitu sebesar $\lambda$.

6. Lakukan proses perhitungan arrival time (at) dengan menjumlahkan iat.

7. Lakukan proses (a) sampai (f) pada tiap node.

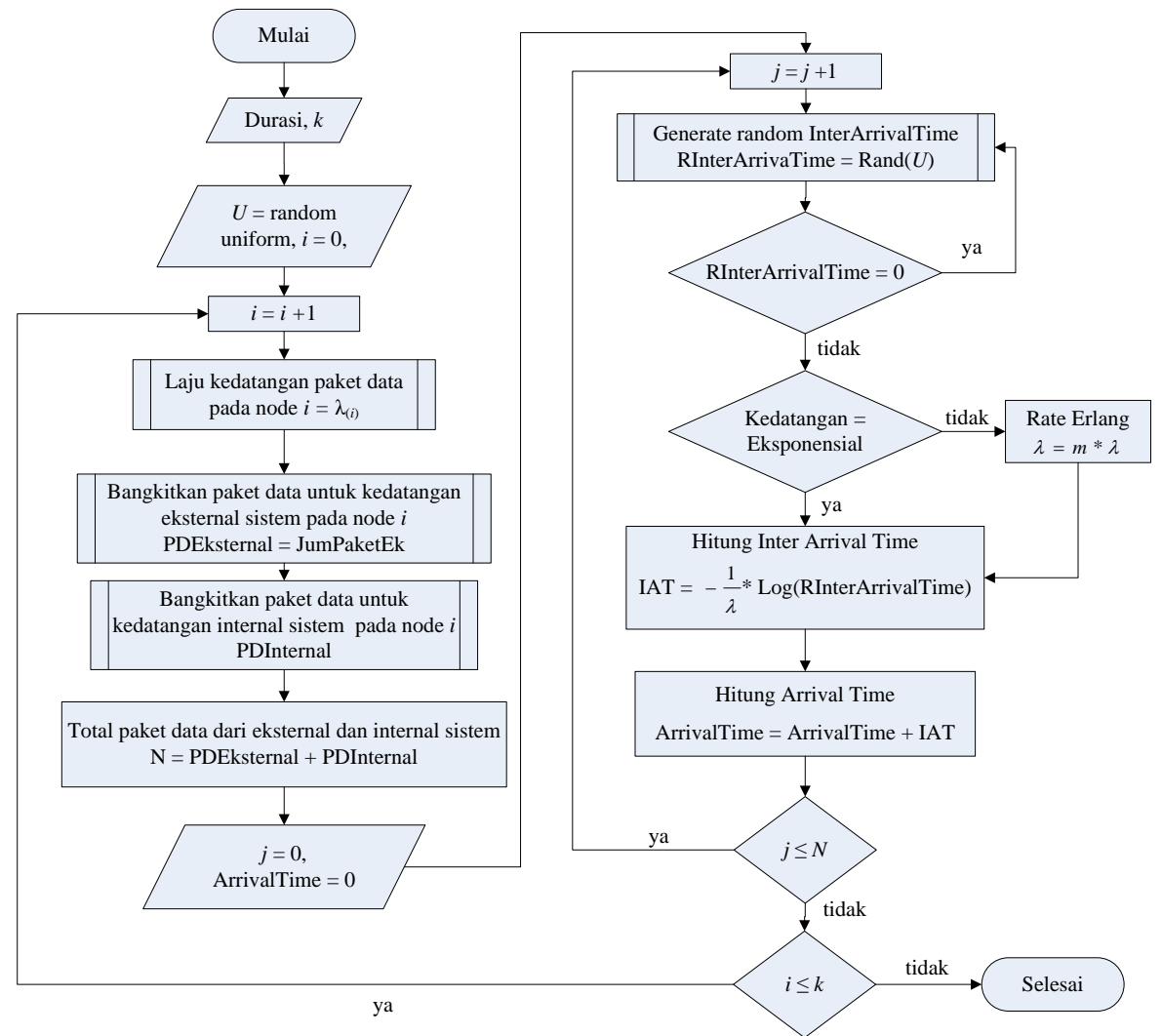

Gambar 3. Flowchart kedatangan paket data 


\section{2.7 Proses Pelayanan Distribusi Eksponensial}

Proses ini digunakan untuk melayani seluruh paket data yang mengantri pada node dengan waktu pelayanan distribusi Eksponensial. Gambar 4 menjelaskan alur proses pelayanan. Langkah-langkah dalam pelayanan paket diuraikan sebagai berikut:

1. Tentukan tingkat pelayanan setiap node.

2. Lakukan proses perhitungan start service time (sst), apabila at lebih besar dari complate time (ct) maka sst adalah at dan jika tidak maka sst adalah $c t$.

3. Lakukan proses perhitungan waiting time (wt) yaitu mengurangkan sst dengan st.

4. Ambil bilangan random yang sudah di generate pada generator bilangan random distribusi Eksponensial.

5. Lakukan proses perhitungan service time (st) dengan persamaan berikut: $-\frac{1}{\mu} \ln ($ BilRandEk)

6. Lakukan proses perhitungan complate time ( $c t$ ) yaitu menjumlahka sst dengan st.

7. Lakukan proses perhitungan time in system yaitu mengurangkan $c t$ dengan at.

8. Lakukan proses (b) sampai (g) sebanyak total paket.

9. Lakukan proses perhitungan nilai karakteristik node.

10. Lakukan proses (a) sampai (h) pada tiap node.

11. Lakukan proses perhitungan nilai karakteristik sistem antrian jaringan pada seluruh node dalam jaringan.

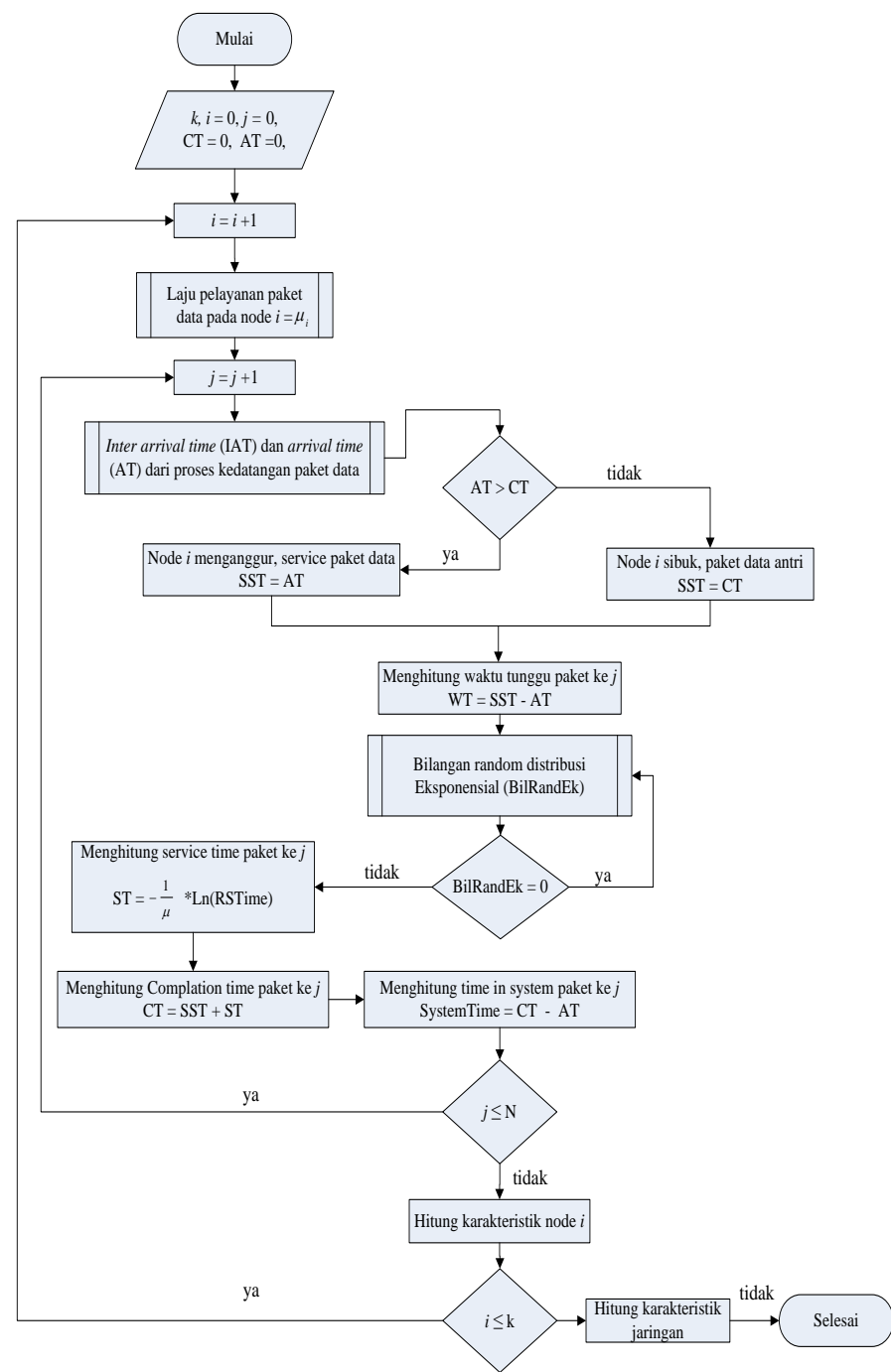

Gambar 4. Flowchart pelayanan distribusi Eksponensial 


\section{2.8 Proses Pelayanan Distribusi Erlang}

Proses ini digunakan untuk melayani seluruh paket data yang menunggu dalam sistem node dengan waktu pelayanan distribusi Erlang. Langkah-langkah dalam proses pelayanan adalah sama dengan distribusi Eksponensial. Tetapi service time yang digunakan dalam distribusi Erlang menggunakan stage untuk mengekuivalenkan mean dengan distribusi Eksponensial, dengan persamaan $s t=-\frac{1}{m^{*} \mu} * \ln ($ BilRandEr $)$. Gambar 5 menjelaskan alur proses pelayanan distribusi Erlang.

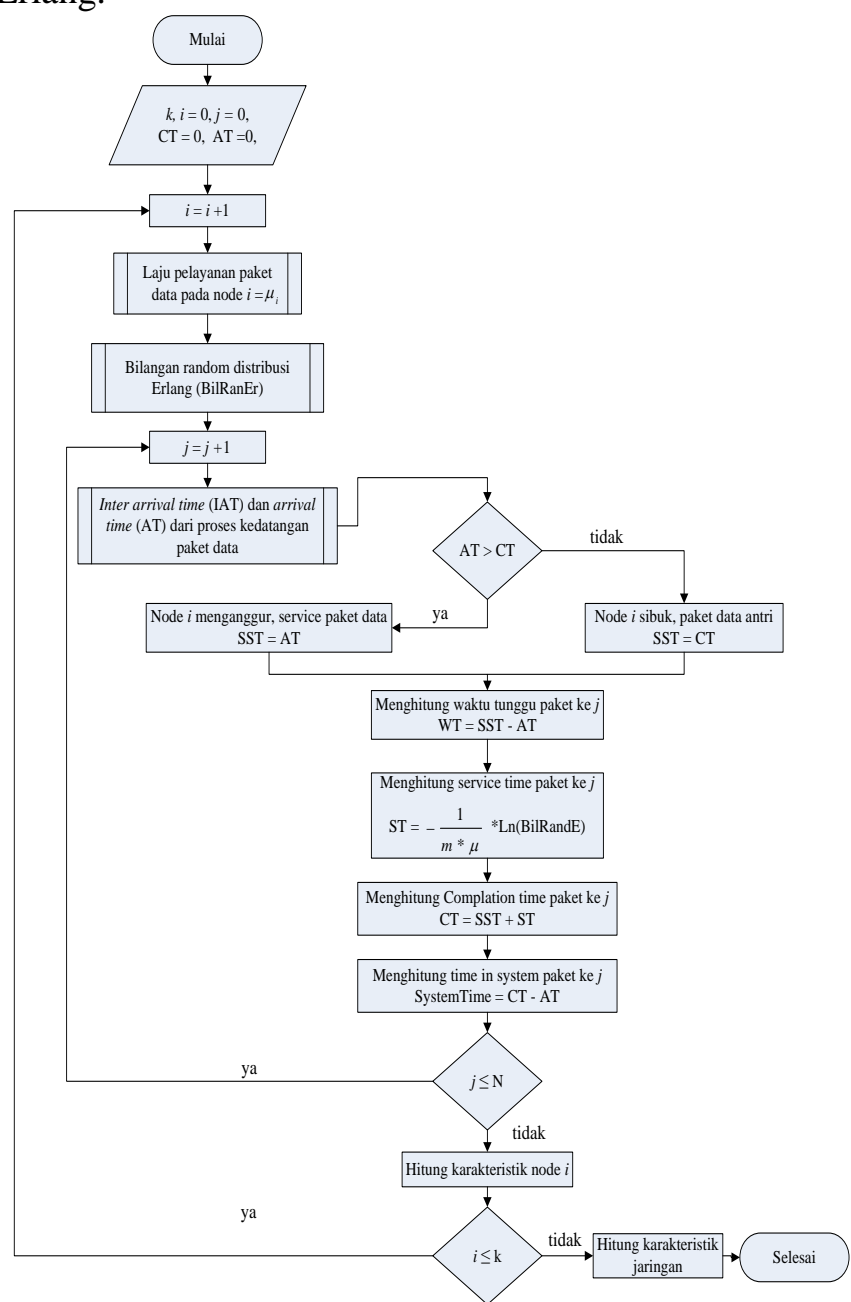

Gambar 5. Flowchart pelayanan distribusi Erlang

\section{2.9 Proses Routing Paket}

Proses routing dilakukan setelah paket data menerima layanan pada node yang dikunjungi, proses ini menentukan aliran paket berdasarkan keputusan routing dan tingkat kedatangan pada masing-masing node. Langkah-langkah proses routing diuraikan sebagai berikut:

1. Tentukan probabilitas routing masing-masing node.

2. Lakukan proses rotasi dengan merandom tujuan paket.

3. Lakukan proses penentuan persamaan total tingkat kedatangan.

4. Tingkat kedatangan eksternal sistem ditentukan pada generator bilangan random distribusi Poisson. 
5. Tingkat kedatangan internal dihitung dengan persamaan: $\sum_{j=1}^{i} p_{(n, i)} \lambda_{(n)}$

6. Persamaan total tingkat kedatangan pada tiap node dihitung dengan menjumlahkan tingkat kedatangan eksternal dengan internal sistem yaitu menggunakan persamaan (1).

7. Lakukan proses perhitungan untuk menyelesaikan persamaan total tingkat kedatangan dengan proses penyelesaian menggunakan eliminasi Gauss.

\section{HASIL DAN PEMBAHASAN}

Sistem pemodelan dan simulasi diimplementasikan dengan program Delphi 7. Pengujian dilakukan dengan controllabel input yang terdiri dari:

Data controllable input dengan durasi 30 menit

1. Data controllable input dengan durasi 1 jam

2. Data controllable input dengan durasi $1.5 \mathrm{jam}$

3. Data controllable input dengan durasi 2 jam

4. Data controllable input dengan durasi $2.5 \mathrm{jam}$

5. Data controllable input dengan durasi 3 jam

6. Data controllable input dengan durasi 3.5 jam

7. Data controllable input dengan durasi 4 jam

Controllable input pada masing-masing durasi disimulasi dengan parameter m-Erlang 2 dan 3. Skenario pengujian dilakukan dengan menentukan pada $n$ berapa proses simulasi dapat dihentikan agar mendapat output yang representatif. Nilai yang digunakan untuk analisis data hasil simulasi dengan menghitung confidence interval dan confidence value yang dalam pengujian ini menggunakan $95 \%$ dengan tigkat error sebesar 5\%. Analisis data hasil simulasi dilakukan dengan mengambil hasil proses simulasi sampai confidence interval terpenuhi. Tahap selanjutnya menghitung nilai rata-rata dan menentukan perubahan tingkat pelayanan terhadap masing-masing karakteristik antara distribusi Erlang dengan distribusi Eksponensial pada tiap parameter m-Erlang.. Semakin besar tingkat pelayanan yang dihasilkan maka karakteristik sistem dari proses pelayanan dikatakan semakin baik. Untuk menentukan karakteristik antrian jaringan maka dihitung rata-rata karakteristik seluruh durasi pada distribusi Eksponensial dan distribusi Erlang.

Tabel 1. Perbandingan rata-rata pelayanan

\begin{tabular}{|c|c|c|c|c|}
\hline \multirow{2}{*}{$\begin{array}{c}\text { Karakte } \\
\text { ristik } \\
\text { jaringan }\end{array}$} & \multicolumn{2}{|c|}{ m_Erlang=2 } & \multicolumn{2}{c|}{ m_Erlang=2 } \\
\cline { 2 - 5 } & Ekp & Erl & Ekp & Erl \\
\hline $\mathrm{Wq}$ & 0.007091277 & 0.016912935 & 0.007093279 & 0.032632464 \\
\hline $\mathrm{Ws}$ & 0.059206533 & 0.068692659 & 0.059212044 & 0.08385516 \\
\hline $\mathrm{Ls}$ & 2.304696075 & 2.67655302 & 2.304562355 & 3.270386684 \\
\hline $\mathrm{St}$ & 0.052107611 & 0.051773201 & 0.052110268 & 0.051216433 \\
\hline Utilitas & 0.052112916 & 0.05177833 & 0.052118769 & 0.051223728 \\
\hline $\begin{array}{c}\text { Rata- } \\
\text { rata }\end{array}$ & $\mathbf{0 . 4 9 5 0}$ & $\mathbf{0 . 5 7 3 1}$ & $\mathbf{0 . 4 9 5 0}$ & $\mathbf{0 . 6 9 7 9}$ \\
\hline
\end{tabular}

Berdasarkan Tabel 1 rata-rata pelayanan distribusi Eksponensial lebih baik dari pelayanan distribusi Erlang pada parameter m-Erlang=2 yaitu distribusi Eksponensial sebesar 0.4950 sedangkan distribusi Erlang sebesar 0.5731 dan pada parameter m-Erlang=3 distribusi Eksponensial sebesar 0.4950 sedangkan distribusi Erlang sebesar 0.6979. Semakin besar nilai parameter m-Erlang menyebabkan rata-rata karakteristik distribusi Erlang semakin meningkat, hal ini berarti bahwa pelayanan akan semakin menurun. Dari hasil pengujian yang dilakukan secara rata-rata distribusi Eksponensial lebih baik dari distribusi Erlang untuk setiap penambahan parameter m-Erlang. 
Tabel 2. Perbandingan rata-rata karakteristik

\begin{tabular}{|c|c|c|}
\hline \multirow{2}{*}{$\begin{array}{c}\text { Karakteristik } \\
\text { jaringan }\end{array}$} & \multicolumn{2}{|c|}{ Rata-rata Karakteristik } \\
\cline { 2 - 3 } & Eksponensial & Erlang \\
\hline $\mathrm{Wq}$ & 0.007092278 & 0.0247727 \\
\hline $\mathrm{Ws}$ & 0.059209289 & 0.076273909 \\
\hline $\mathrm{Ls}$ & 2.304629215 & 2.97346985 \\
\hline $\mathrm{St}$ & 0.05210894 & 0.051494817 \\
\hline Utilitas & 0.052115843 & 0.051501029 \\
\hline Rata-rata & $\mathbf{0 . 4 9 5 0 3 1 1 1 3}$ & $\mathbf{0 . 6 3 5 5 0 2 4 6 1}$ \\
\hline
\end{tabular}

Hasil pengujian berdasarkan rata-rata karakteristik seluruh durasi simulasi dan input parameter m-Erlang pada Tabel 2 dijelaskan sebagai berikut: rata-rata waktu tunggu paket data dalam antrian pada sistem jaringan (Wq) distibusi Eksponensial sebesar 0.0071 dan distribusi Erlang sebesar 0.0248, rata-rata waktu tunggu paket data pada node di dalam sistem jaringan (Ws) distibusi Eksponensial sebesar 0.0592 dan distribusi Erlang sebesar 0.0763, rata-rata jumlah paket dalam sistem jaringan (Ls) distibusi Eksponensial sebesar 2.3046 dan distribusi Erlang sebesar 2.9735, rata-rata waktu pelayanan paket data dalam sistem jaringan (St) distibusi Eksponensial sebesar 0.0521 dan distribusi Erlang sebesar 0.0515 dan probabilitas node sistem jaringan sibuk (Utilitas) distibusi Eksponensial sebesar 0.05211 dan distribusi Erlang sebesar 0.0515. Rata-rata seluruh karakteristik distribusi Eksponensial sebesar 0.4950 sedangkan distribusi Erlang sebesar 0.6355.

Salah satu contoh grafik perbandingan karakteristik distribusi Eksponensial dengan distribusi Erlang berdasarkan controllable input 30 menit ditunjukkan pada Gambar 6.

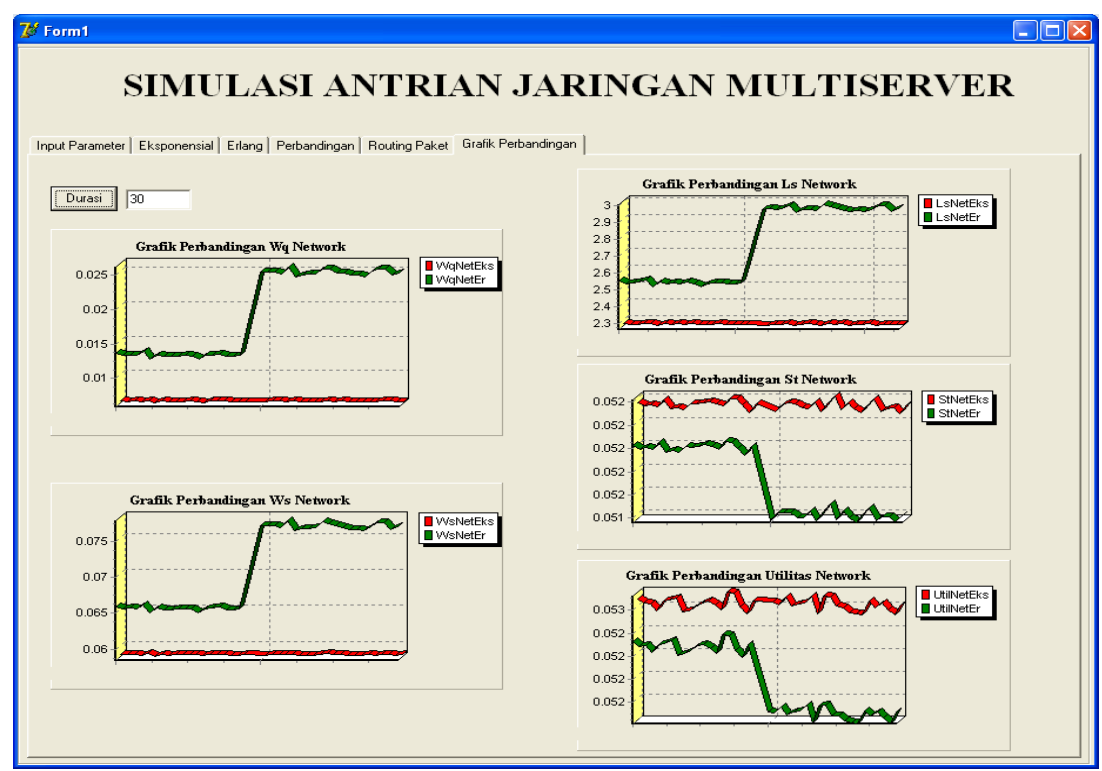

Gambar 6. Grafik perbandingan durasi 30 menit

Model simulasi yang dibangun memperlihatkan logika implementasi sudah sesuai dengan logika diagram alur dari masing-masing proses. Berdasarkan hasil pengujian yang dilakukan, model sistem simulasi dapat menentukan karakteristik sistem yang akan digunakan sebagai bahan pertimbangan dalam manajemen jaringan kedepannya. 


\section{KESIMPULAN}

Terdapat beberapa kesimpulan yang dapat disampaikan terhadap hasil pemodelan dan simulasi antrian jaringan paket data adalah:

1. Pemodelan dan simulasi yang digunakan untuk penentuan karakteristik sistem antrian jaringan dengan waktu pelayanan distribusi Eksponensial dan distribusi Erlang berpengaruh terhadap nilai karakteristik antrian jaringan. Rata-rata karakteristik distribusi Eksponensial sebesar 0.4950 sedangkan distribusi Erlang sebesar 0.6355 pada input parameter m-Erlang 2 dan 3.

2. Metode open Jackson dapat digunakan dalam pemodelan dan simulasi dengan menerapkan waktu pelayanan paket data berdistribusi Eksponensial dan Erlang. Waktu pelayanan distribusi Eksponensial memberikan rata-rata pelayanan lebih baik dari distribusi Erlang pada input parameter $m$-Erlang $=2$ dan input parameter $m$-Erlang=3. Hasil ini menunjukkan bahwa semakin meningkat nilai parameter m-Erlang menyebabkan rata-rata pelayanan distribusi Erlang semakin besar, hal ini berarti tingkat pelayanan distribusi Erlang akan semakin menurun dibandingkan distribusi Eksponensial.

3. Hasil yang diperoleh dari model yang dibangun secara rata-rata karakteristik sistem antrian jaringan menunjukkan waktu pelayanan distribusi Eksponensial lebih baik dari waktu pelayanan distribusi Erlang pada input parameter m-Erlang $\geq 2$.

\section{DAFTAR PUSTAKA}

[1] Baskett, F., Chandy, K.M., Muntz, R.R. and Palacios, F.G., 1975, Open, closed and mixed networks of queue with different classes of customers, J. ACM. 22, 248-260

[2] Gordon, W.J. and Newell, G.F., 1967, Closed Queueing System with Exponential Server in Operations Research 15 (2), 254-65.

[3] Jackson, J.R., 1963, Jobshop-like queueing systems, Manag, Sci. 10, 131-142.

[4] Lam, S. S., dan Wong, J. W., 1982, Queueing Network Model of Packet Switching Network, Ed.2, North-Holland, Canada.

[5] Koizumi, N., 2002, Queueing Network Model With Blocking: Analysis Of Congested Patients Flows In Mental Health System, Disertasi, University of Pennsylvania, Pennsylvania.

[6] Sezer, A.D., 2005, Dynamic Importance Sampling for Queueing Network, Dissertasi, Division of Applied Mathematics at Brown University, Rhode Island.

[7] Darmawan, G., 2009, Pengaturan Kedatangan Eksternal Optimal Pada Antrian Jaringan Jackson, Seminar Nasional Matematika 2009 FMIPA Universitas Negeri Jember. Jember.

[8] Simamora, R.J., 2010, Simulasi Antrian Multiple Server Dengan Pola Kedatangan Berkelompok, Tesis, Program Pasca Sarjana Ilmu Komputer, Universitas Gadjah Mada, Yogyakarta.

[9] Hoover, S.V., and Perry, R.F., 1989, Simulation A Problem - Solving Approach, Digital Equipment Corporation \& Northeastern University.

IJCCS Vol. 7, No. 2, July 2013 : $177-188$ 